\title{
Teacher professionalism in digital era
}

\author{
Sugiyanto Sugiyanto ${ }^{1}$, Nur Ahyani ${ }^{2}$, Nila Kesumawati ${ }^{2}$ \\ ${ }^{1}$ Sekolah Menengah Kejuruan Negeri 4 OKU, Indonesia \\ ${ }^{2}$ Universitas PGRI Palembang, Indonesia
}

\begin{tabular}{l}
\hline Article Info \\
\hline Article history: \\
Received Jul $15^{\text {th }}, 2021$ \\
Revised Aug $18^{\text {th }}, 2021$ \\
Accepted Aug $30^{\text {th }}, 2021$ \\
\hline
\end{tabular}

\section{Keyword:}

Teacher professionalism Quality of education Digital era

\begin{abstract}
Technological developments make changes in life. Students are in a digital environment full of information. Countries change educational goals. Many educational innovations have also been carried out to support this. The hope of educational innovation is the support and integration of information and communication technology (ICT) in the learning process. So that there is an increase in the quality of student learning. Students today must have communication, collaboration, critical thinking and creative and innovative skills. These skills must be included in the learning process in class. To support this, all teacher competencies must be improved, especially professional competences. This research uses literature study. The purpose of this study is to reveal how the professionalism of teachers in the 4.0 revolution era in improving the quality of education.
\end{abstract}

(C) 2021 The Authors. Published by IICET.

This is an open access article under the CC BY-NC-SA license (https://creativecommons.org/licenses/by-nc-sa/4.0

\section{Corresponding Author:}

Sugiyanto, S.,

Sekolah Menengah Kejuruan Negeri 4 OKU, Indonesia

Email: sugi66846@gmail.com

\section{Introduction}

The era of the industrial revolution 4.0 also had an impact on the world of education. Because the 4.0 industrial revolution requires teachers to be able to take advantage of the super-fast advances in information technology to improve the quality of the teaching and learning process and prepare superior human resources. Therefore, improving teacher competence is important. The use of digital technology in the learning process, completing various tasks, and increasing teacher competence cannot be separated from the flow of information and technology developments. Facing these challenges, teachers as the front guard in the world of education are required to be ready to change and adapt.

The role of the teacher will not be replaced by any sophisticated machine. This is because teachers are needed to shape the character of the nation's children with character, tolerance and values of kindness. The teachers are also able to foster social empathy, build imagination and creativity, and strengthen the spirit of national unity and integrity. The role of teachers is increasingly important and strategic now, this is because currently there is a shift in development priorities of the government. After focusing on infrastructure development, starting in 2019 the government is making efforts to improve the quality of human resources (HR). The development of the quality of human resources means relying on teachers, so that teachers are expected to be able to become agents of transformation of strengthening human resources in building student talents, managing 3 lessons more creatively, and shaping the character of the nation's children. For this reason, teachers are required to continue to improve professionalism towards 21 st century education. 
The world of education today is also required to be able to equip students with 21 st century skills. These skills are skills of students who are capable of Problem Solving, Creativity, Communication Skills and collaboration. In addition, the skills to seek, manage and convey information are also skilled in using technology and information. The abilities that must be possessed in the 21st century include: Leadership, Digital Literacy, Communication, Emotional Intelligence, Entrepreneurship, Global Citizenship, Problem Solving, Team-working. Meanwhile, the three educational issues in Indonesia today are character education, vocational education, and innovation [1]. The aims and objectives of this study are to reveal how the professionalism of teachers in the revolutionary era 4.0 in improving the quality of education.

Changes in the character of society fundamentally as happened in the 21 st century, certainly has implications for the character of teachers. In a progressive view, changes in the characteristics of society need to be followed by a transformation of teacher culture in the learning process. If now society has changed to a digital society, then teachers also immediate need to transform themselves, both technical and socio-culturally. Therefore, it is necessary to define what kind of teacher character is able to transform themselves in the digital era of the 21st century today. There is a saying that, the book is replaced by technology, but the role of the teacher cannot be replaced, even has to be strengthened. In today's world, in the 21st century, teachers must be able to take advantage of digital technology to design creative learning. The ability of teachers to educate in the era of digital learning needs to be prepared by strengthening cyber pedagogy in teachers. Teachers have more roles as facilitators and must be able to utilize existing digital technology to design creative learning that enables students to be active and think critically

\section{Literature Review}

Professionalism according to Webstar from the word profession is an activity in order to fulfill the obligation to carry out a special task diligently. Another definition of a profession is a field of work that is based on expertise, education such as vocational and certain skills [2]. Understanding scientific professionalism refers to ideas, streams or initiatives about the work that must be done professionally, which leads to professionalism [3]. Meanwhile, teacher professionalism is an educator who performs obligations with high expertise as a source of life. In exercising their professional authority, educators must have a variety of intellectual skills that include cognitive skills (thinking), affective skills (behavior) and psychomotor competencies (skills) [4].

Educator professionalism can be carried out in several stages, the first is to master the predetermined professional standards. The second stage, achieving qualifications and skills in accordance with predetermined conditions. The third stage, creating large and productive relationships through the professional community. The fourth stage is to improve a culture and work ethic that prioritizes high quality services to members. And the fifth stage, developing creative and innovative in utilizing communication, information technology to keep up with the times in order to be able to manage lessons [5]. Educator professionalism needs to be needed in accordance with the needs of teachers in order to continue to develop.

Indonesian teacher professionals must have broad insight as an implementation of the nation, both in science and technology in the 21st century, as a continuous development of professional skills [6]. So it can be understood that teacher professionalism can be done by implementing technology in learning. According to Turban, information technology is a way to describe a number of information systems, users and management for the benefit of the organization [7]. The definition of communication information technology is technology that uses computers and uses high-progress connection lines that contain voice, data and video [8].

Technology has three functions, the first is to create a fun and exciting learning atmosphere. Second, providing skills to use technology, which can reveal the challenges of relevance outside the school environment. Third, it can be used as learning tools using the application and utility programs. For school learning, there are two main approaches to using technology, including students being able to learn "from" technology and "with" technology. The use of technology in learning is carried out to increase effectiveness in the implementation of teaching and learning processes so that students are expected to be able to improve learning outcomes or student achievement and individual values in using technology correctly, positively and productively [9]. One of the main factors in increasing human resource capacity and institutional capacity is the implementation of synchronous information and communication technology in the world of education. Information and communication technology has entered into everyday life, including in the world of education [9].

Competence is an absolute requirement on the duties and responsibilities of being the owner of the knowledge, skills and abilities demanded by one's position. Competence is a description of the qualitative nature and behavior of teachers that seems very meaningful [10]. Competence is seen as a pillar or a performance terrace of a profession [11]. Teacher competence is rational behavior to achieve goals whose 
requirements are in accordance with the expected education. Teacher competence is a set of mastery of abilities that must be present in teachers in order to realize their performance appropriately and effectively [2].

Teacher competence is the ability or skill of educators to create an educational communicative atmosphere between teachers and students which includes cognitive, affective, and psychomotor aspects. In an effort to learn something based on planning, the evaluation and follow-up stages come in order to achieve teaching goals [12].

By increasing the teaching competence of teachers, teachers are expected to be able to maintain their teaching profession, increase their performance in a better direction and be able to make new innovations in carrying out their duties and responsibilities. This increase also allows a development that is able to lead teachers to progress and be able to accompany changes that occur in their environment, so that the resulting productivity or performance is able to provide optimal satisfaction for educating consumers determined by improving the quality of education.

\section{Method}

It is interesting to know about the problems of teacher professionalism in the digital era. Given the further publication on this topic is still rare. The writing of this paper is a type of literature description article obtained from relevant scientific articles obtained from internet search media library engines: Proquest, researchgate, google scholar and other search engines with keyword searches "distance learning problems" to find related scientific paper publications/Relevant to the topic. Then the articles are studied and then the material is presented in the author's point of view, which is then explained from the author's point of view.

\section{Results and Discussions}

The 21st century, which is marked by the presence of the media era (digital age) greatly influences the management of learning and changes in student characteristics. 21st century learning becomes imperative to integrate information technology and communication, student-centered learning. In the development of 21st century learning, teachers are required to change conventional learning patterns that are centered on the teacher (teacher centered) into student-centered learning (student centered). Abundant learning resources are not only teacher resource persons, so that the teacher's role is to become a facilitator, mediator, motivator and leader in the learning process. The conventional learning pattern can be understood as learning where the teacher gives a lot of lectures (transfer of knowledge) while the students listen more, take notes, and memorize.

The ability of pedagogy with conventional patterns is deemed inappropriate for the current era. The characteristics of students of the 21st century are very different from students of the previous era. In this $21 \mathrm{st}$ century, a person must have four skills (communication, collaboration, critical thinking and problem solving and creativity and innovation). These skills should be reflected in the learning that will be carried out by a teacher. 21st Century skills can be integrated into the implementation of learning, so that the choice of methods, media and classroom management actually enhances these skills. That is why it is imperative that teachers' pedagogical abilities complete the characteristics and skills needed in the 21st century.

The characteristics described above are suitable for the professional development of teachers in the 21st century. Therefore, teachers continue to increase their interest in reading by increasing their collection of books. Whenever there is a learning problem, the teacher needs to increase knowledge through reading books, both printed and digital which can be accessed via the internet. Without high reader interest, teachers in the current era of cyber pedagogy will lag behind the knowledge of their students, which will reduce the credibility or authority of the teacher. The loss of teacher authority will have a serious impact, not only on decreasing the quality of learning, but also for the progress of a nation.

Efforts to achieve national education require teachers who have quality standards of competence and quality professionalism. Teacher professional policies as a transformative stage in order to change the rank of educators as professions can improve the quality of educators in a systemic and sustainable manner [13]. Professional educators are required to carry out improvement and development of educational capabilities and qualifications continuously following changes and advances in art, science and information technology [14]. The development of technology and information is one of the challenges of teacher professionalism in the future [5].

The characteristics of professional educators, there are several levels, the first being capable, namely that educators has a level of expertise and knowledge, to improve the quality of education and be able to turn it into something productive for educators and their students. Second, innovators, namely educators always 
create new ideas or methods to find solutions to the difficulties of students in the learning process. The three developers, namely professional educators who always develop themselves and develop various models and methods of teaching and learning activities to attract attention and foster students' enthusiasm for learning [15]. Professional educators can be seen from their responsibility in serving the role of educators in the nation, society, parents, religion and students. Professional educators are responsible socially, intellectually, morally, and spiritually [16].

The quality of education is viewed from two aspects including learning outcomes and the learning process. And efforts to improve the quality of the teaching and learning process have led to the emergence of initiatives from students and teachers [17]. To support or improve teacher professionalism in achieving educational goals, namely by using and utilizing information communication technology (ICT) in teaching and learning activities. Because in the era of the industrial revolution 4.0, it experienced developers in all forms including technological developments. In the teaching and learning process, innovators and developers are needed to improve their backwardness in accordance with the development of the modern era which is influenced by technological developments.

In the world of technology education more often uses the term Information Communication Technology (ICT) [18]. UNESCO has officially defined the term information and communication technology (ICT) and in Indonesian it is known as ICT [19]. Learning that makes maximum use of ICT can improve student achievement. Teachers who are not professional in developing learning models because they do not master technology cannot improve the quality of education in accordance with the times.

The foundation of teacher competency development is Law No. 14 of 2005 on teacher competence covering pedagogical competence, personality competence, social competence, and professional competence. Each competency can be described as follows; Competence is performed (ability to do) which is motivated by mastery of knowledge, attitudes and skills. This implies that the quality of performance is determined by the mastery of knowledge, attitudes and skills. The higher the quality of mastery of knowledge, attitudes and skills, the higher the performance, and vice versa. So there is a high positive correlation between the level of mastery of knowledge, attitudes, and skills with the established competencies. Competence is a set of mastery of abilities that must be present in the teacher in order to achieve proper performance as a teacher [20] A professional teacher must have 4 competencies. These competencies include:

(1) (Pedagogical competence includes teacher understanding of students, design and implementation of learning, evaluation of learning outcomes and development of students to actualize their various potentials. Included in this ability includes sub-abilities; (a) organize classrooms; (b) creating a conductive classroom climate; (c) motivating students to learn habits; (d) providing verbal and non-verbal reinforcement; (e) providing clear instructions to students; (f) responded to classroom disturbances; and (g) refreshing the class if the class is getting tired Pedagogic competence is the teacher's ability to manage learning such as understanding student characteristics, the ability to plan learning, evaluating learning outcomes, and the ability to develop various potentials of students. Usually, teachers are required to be adapted to the development of science and technology information and communication and being able to use it in the learning process. This means that the ability of teachers, especially digital literacy, needs to be integrated into the learning process.

(2). Personality competence is a personal ability that reflects a stable, stable, mature, wise, dignified personality and is a role model for students and has noble character. (3) Social Competence is the ability of teachers to communicate and interact effectively with students, fellow educators, education personnel, parents / guardians of students and the surrounding community. And (4) Professional competence is the mastery of learning material broadly and deeply which includes mastery of subject curriculum materials in schools and the scientific substances that cover the material. This competency is also called mastery of teaching material sources or often referred to as the field of study expertise. The four competencies, in their implementation, constitute a complete rule, because someone who has this competence is a requirement to be categorized as a professional teacher.

To achieve professional teachers requires a fairly long process, in accordance with Article 20 of Law No. 14 of 2005 that in carrying out professional duties, teachers have the right to: (a) Plan learning, which is of good quality and assess and evaluate learning outcomes. (b) Develop and improve academic qualifications and competencies in a sustainable manner in line with the development of science, technology and the arts. (c) Acting in an objective and non-discriminatory manner based on considerations of gender, religion, ethnicity, race, certain physical conditions, or family background, and the socioeconomic status of students in learning. (d) Upholding laws and regulations, laws and teacher codes of ethics as well as religious and ethical values. (e) 
Maintain and cultivate national unity and integrity, and (f) Teachers must have the ability to use ICT in the learning process

\section{Conclusions}

The digital era is making changes in education in Indonesia. Schools are required to prepare students with 21st century competencies. 21st century skills, namely Problem Solving, Creativity, Communication Skills and collaboration. Responding to existing challenges, teachers are required to be professional in carrying out their duties. Professional teachers must have four competencies, namely personal competence, social competence, pedagogic competence and professional competence. In addition, professional teachers must also follow technological developments so that they can be adapted to the learning process in the classroom. All of this is in an effort to improve the quality of learning and produce students who are ready to face the digital era.

\section{References}

Wibawa, S. 2018.Pendidikan dalam Era Revolusi Industri 4.0. Indonesia

Kunandar. 2009. Guru Profesional Implementasi Kurikulum Tingkat Satuan Pendidikan (KTSP) dan Sukses dalam Sertifikasi Guru.Jakarta:PT Raja GrafindoPersada.

Anwar, M. N, Badawi. 2019. Profesionalisme Guru, di Era Revolusi Industri 4.0. Prosiding Seminar Nasional, Pendidikan Program Pascasarjana Universitas PGRI Palembang.

Asmarani, N. 2014. Peningkatan Kompetensi Profesional Guru di SekolahDasar. Jurnal Administrasi Pendidikan. Vol. 2, No. 1

Muhlison. 2014. Guru Profesional (Sebuah Karakteristik Guru Ideal Dalam Pendidikan Islam). Jurnal Darul` Ilmi, Vol. 02, No. 02

Arifin. 2001. Profesionalisme Guru Analisis Wacana Reformasi Pendidikan dalam Era Globalisasi. Simposium Nasioanal Pendidikan di Universitas Muhammadiyah Malang

Turban, McLean and Wetherbe J. 2002. Information Technology for Management, Third Edition. USA: John Wiley \&Sona.

William and Sawyer. 2003. Using Information Technology: A Pracrical Introduction to Computers \& Communication. Mcgraw-Hill.

Sudarma. 2008. Cara Mudah dan Cepat Memiliki Website Gratis di www.100webspace.com dengan Aura CMS Langsung PraktikOn Line Internet. Yogyakarta: Gava Media

Usman, Moh, U. 2005. Menjadi Guru Profesional. Bandung: RemajaRosdakarya.

Saud, U, S. 2009. Pengembangan Profesi Guru. Cet. I. Bandung: Alfabeta

[Suryosubroto. 2010. Manajemen Pendidika di Sekolah. Jakarta: RinekaCipta.

Sujianto. 2012. Pengembangan Profesionalitas Berkelanjutan Guru Bersertifikat Pendidik Di

SMK Rumpun Teknologi. Jurnal Teknologi Dan Kejuruan. Vol. 35, No. 1

Mustafa. 2007. Upaya Pengembangan Profesionalisme Guru Di Indonesia. Jurnal Ekonomi \& Pendidikan.

Vol. 4, No. 1

Roskina, S.M., 2008, Profesionalitas Guru Dalam Peningkatan Kualitas Pembelajaran, Inovasi, Vol. 5, No. 2

Yusutria, 2017, Profesionalisme Guru Dalam Meningkatkan Kualitas Sumberdaya Manusia, Jurnal Curricula, Vol. 2, No. 1

Degeng, N.S, 2004, Teori Pembelajaran, Malang: UM Press

[Miarso, Y.H., 2004, Menyemai Benih Teknologi Pendidikan, Jakarta: Kencana

Husain, C., 2014, Pemanfaatan Teknologi Informasi dan Komunikasi dalam Pembelajaran di SMA Muhammadiyah Tarakan. Jurnal Kebijakan dan Pengembangan Pendidikan. Vol. 2, No. 2.

Djumiran, dkk.2009. Direktorat Jenderal Pendidikan Tinggi. Departemen Pendidikan Nasional. 